\title{
Brief Analysis on the Design of School Uniforms in Films and Television Programs
}

\author{
Miao Yu \\ College of Fashion \\ Dalian Polytechnic University \\ Dalian, China
}

\begin{abstract}
School uniforms in different countries contain the special cultural connotation of the specific country. School uniform in films and television programs not only conveys the content and meaning of the film itself, but also represents the national culture of the country and carries forward to the whole world, which made it even more popular. School uniform culture has some influence on films and television programs. At present, there are many studies on costume culture in films and television programs; however, there is very few research on the school uniform culture. This paper tries to open up a new research angle, which emphasizes on the analysis of the aesthetic value of school uniform in films and television programs in different countries. This research is made on the dual base of film culture and costume culture, and aims to explain the unique artistic value of film through the research on school uniform aesthetic meaning.
\end{abstract}

Keywords-films and television programs; design of school uniforms; character modeling

\section{INTRODUCTION}

Films and television programs demonstrate the unique artistic charm through their special linguistic forms, which have distinct characters like direct, clear and specific. It is because that it conveys emotion to the audience directly through pictures and brings the strong visual communication effect, among which the design of costumes is an important part. As we all know that costume is not only one of the major manifestation mode in character modeling in films and television programs, but also plays an irreplaceable role in representing characters. Among all kinds of costume, school uniform is always loved by the public due to its special design and concept. School uniform is mainly popular in school culture. However, with time passing by, school uniform has become a special and popular culture form.

\section{ThE ORIGIN OF SCHOOL UNIFORM CULTURE}

School uniform in fact is the uniform wear by students under the school regulation. It is also a kind of cultural symbol. School uniform culture was originated in Britain, with special social and historical reasons. There were many schools founded by Britain church, which were called as Bluecoat Schools. Bluecoat was the typical school uniform in the early times. As the earliest school uniform in the world, it has been endowed with deep historical connotation, wearing which is the symbol of belief and honor. During its development, British school uniform has developed into different forms, like blue uniform, Boy Scout uniform and military student's uniform and so on.

Compared with the development of school uniform in European countries, Asia countries started late in school uniform from aspects like origin, style and developing process, and has less influence than European countries. Japan paid special attention to its national traditional culture and education, thus Japanese school uniform has been appeared as early as in 1873. In 1886, Japanese Education Ministry officially issued the instruction of unifying senior high school uniform and started producing and selling school uniform in 1889. Especially that the sailor suit of girl student's school uniform has became the symbol of school uniform.

South Korean girl student's school uniform was first started in Ewha Woman's University, the female education institution found in 1886. In order to solve the girl students' economic difficulties, the university provided hanbok school uniform for all students. In 1907, Sookmyung Women's University first employed the Western-style school uniform. In 1980, South Korea implemented the policy of liberalization on school uniform. The production and selling of school uniform have employed commercialized operation, and many specialized school uniform brand have appeared. Under the background of commercial competition, school uniform in South Korea has developed a virtuous circle characterized by high quality, fine goods and cheap price. The school uniform brands always employ hot Korean stars as their spokesperson. South Korean school uniform has absorbed the characteristics of European and Japanese school uniform and developed into its own style, which is richer in style and more colorful than Japanese school uniform.

Since the Revolution of 1911, China has started the wave of establishing modern schools. Different schools specialized in different subjects have been established, including military schools, vocational schools, medicine schools and so on. The school authorities provided unified clothes, hats and shoes for students, which is probably the starting of Chinese student's uniforms. Since the introduction of Western uniforms by overseas Chinese students, Western style school uniform has been loved and strongly pursued by young students. Since China's reform and opening up in 1980s, some schools in cities started to made school uniforms for students if allowed by 
conditions and environment. For boy students, the uniform was white shirt with sky blue collar and shorts; for girl students, the uniform was sky blue suspended skirt and white shirt. There were two white bars on the uniform, which seemed very energetic.

Along with the rapid development of mass media including Internet, film and television and so on, teenagers pursue the common lifestyles and shared values. As the representative cloth of teenagers, school uniform also has become the distinct symbol of teenager culture.

\section{SCHOOL UNIFORM CULTURE IN FILMS AND TELEVISION PROGRAMS}

The choice of cloth may be one of the earliest human aesthetic forms. Because of the different living environment and cultural background of different nations and countries, the style of cloth is also various, and thus forms the colorful cloth culture. School uniform in films and television programs can be regarded as the special mode of presentation of costume culture.

Generally speaking, the frequency of school uniform in films and television programs is not high, which mainly appears in those school style works. Due to the different cultural background, the design of school uniform in films and television programs in different countries is different in style and form, not only provide us with various school culture, but also make us experience the deep cultural connotation and aesthetic value conveyed by the film.

The audiences worldwide have learned the American style school uniform culture from those American films like High School Musical, Legally Blonde, and Gossip Girl and so on, while the Chinese movies like My Deskmate, The Left Ear, and Fleet of Time have demonstrated the Chinese style school uniform culture.

Films and television programs in Japanese film works mainly display the school uniform culture represented by sailor suit. For example, Shunji Iwai's Love Letter, Shinji Soomai's Sailor Suit and Machine Gun and so on. Besides those movies, Japanese animation works also have fully demonstrated the school uniform culture represented by sailor suit, such as in Sailor Moon, Lucky Star, Inuyasha, Jigoku Shoujo and so on. The heroes in those animation works mainly wear school uniforms. The teenagers from different countries would imitate the heroes in those animation works and wore Japanese sailor suits due to their love to the animation films. This kind of COSPLAY culture is also a kind of teenager culture.

\section{VALUE OF THE DESIGN OF SCHOOL UNIFORM IN FILM AND TELEVISION PROGRAMS}

School uniform is one of the important part of visual convey in films and television programs, which can be found through the whole work. On the one hand, it can display the personality of the character. On the other hand, it is also the carrier of the figure's fate and the film background. School uniform in films and television works catch the audience's eyes through visual pictures, and then make audience experience the aesthetic value of school uniform through visual experience.

First, it represents the characteristic features of the figures.

The personalities of characters in films and television programs are reflected in different aspects. The audience can understand the personalities of characters generally through their clothing matching. School uniform is the main cloth in the youth films. However, the styles of school uniform in different countries are various, which make it different in presenting the characters. For example, sailor suit is the representative school uniform in the Shunji Iwai's Love Letter, in which the sailor suit was wear by the whole school students during the middle school time. The director made great efforts on the color of school uniform. The heroine in the movie wore dark blue sailor suit uniform, while the other girl students wore blue and white color uniforms. The audience can feel the heroine's silent and melancholy personalities from the color of her uniform. Besides, the color blue represents depressing, and this also means that there would be no result of the love between the heroes.

Second, give prominence to the artistic style of the film.

Clothing in films and television programs can reflect the artistic style of the film as a kind of silent language. For example, the heroine of the famous teenager film Legally Blonde III wore the school uniform that makes her look young and beautiful. The usually used blue coat of common school uniform was matched with rarely used pink skirt, with white high socking and pink shoes. This fashion and avant-garde school uniform made the film full with bright and comic atmosphere.

Even though school uniform is the brand name of teenager films, it also plays an important role in non-mainstream style film. As is shown in "Fig. 1", the Japanese senior high school killer GOGO in American movie Kill Bill I wore cute light blue plaid skirt, which was a typical image of a common and weak girl student. However, she turned into cold face quickly and began to kill others. The big contrast between the appearance and behavior surprised the audience greatly, and also gave prominence to the artistic tone of violence aesthetics in the film. At the same time, in Japanese film Battle Royale, the naive students were trapped in an isolated island by the adults and were required to kill each other to escape the island. Only the one who survived at last has the chance to leave the island "Fig. 2". In the movie, the school uniform was in light maize-yellow, aiming to achieve stronger effect after it was painted by blood. The bow tie and tie were designed into blood red that indicates the brutal plot of mutual slaughter. "Fig. 3" There was lovely lace on the girl student's skirt, which was in contrast with the poster that they were holding lethal weapons in their hands. Classmates that wore same school uniforms changed into enemies to kill each other. School uniform that used to represent a sense of belonging indicates the death and living instead. In this way, school uniform brought great shock to the audience's hearts, which was also the aim of the movie to arouse people's deep thinking. 


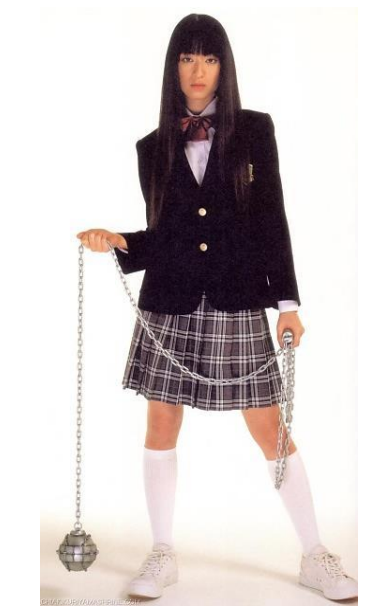

Fig. 1. Photo of Kill Bill

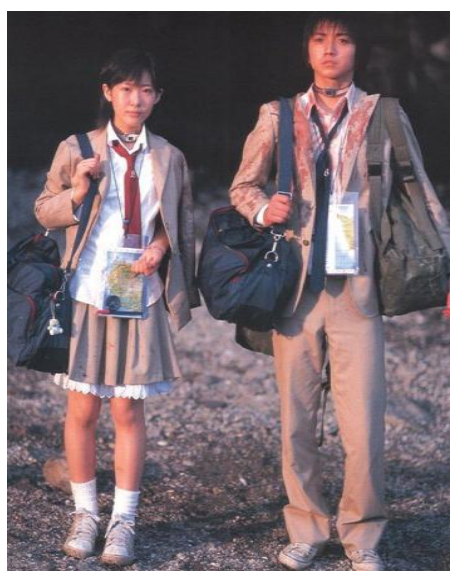

Fig. 2. Photo of the film Battle Royale

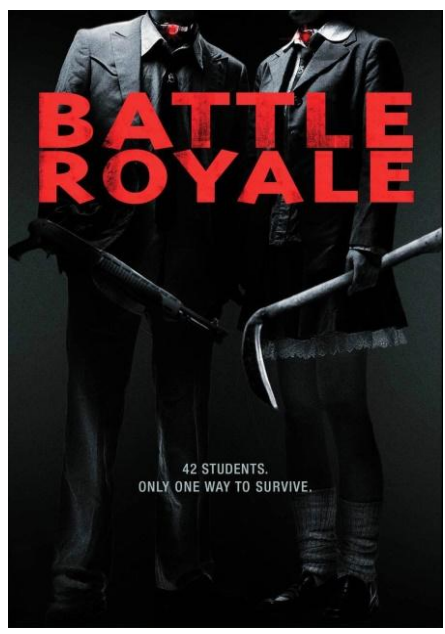

Fig. 3. Poster of the film Battle Royale

In these films, the design of school uniform has played very important role in reflecting the theme and the artistic style.

\section{The CUltural MeANing OF SCHOOL UNIFORM'S Aesthetic Value}

Along with the growing influence of films, as one of the most important factors, clothing has played deep influence on the film due to its special artistic charm, and pushed the background culture contained in the movie to wider space.

First, enlarge the influence of the film.

A good film or television program not only has exciting plot, but also gives full space for the audience's imagination. As the important factor of the detailed design, clothing plays an incomparable role in enlarging the influence of the film. As the name card of teenager film, school uniform not only can reflect the aesthetic style of the film and the personalities of characters, but also has its own special charm. For example, after the release of Legally Blonde III, the fashionable school uniform was very popular among the public. The love towards the school uniform enlarged the influence of the film virtually, which helped the box office to achieve better result. In South Korea TV series Boys Over Flower and Palace, the beautiful school uniforms wear by the heroes and heroines were deeply loved by teenagers worldwide, who began to wear the similar uniform as in the film.

Second, enlarge the influence of culture behind the film.

Clothing in the film not only represents the film itself, but also contains the cultural meaning behind the film. The style of school uniform in movies also reflects the cultural connotation of the country. For example, the design of senior high school uniform in American TV series Gossip Girl is fashionable, free and relax, which is the representation of European and American culture. Compared with European and American culture, the oriental culture is no implicit, which is also reflected in the design of school uniform. "Fig. 4" In the South Korean TV series Cheese in the Trap, the heroine wore skirt that was adapted on the base of sailor suit. On the other hand, some clothing brand related to teenager culture always incorporate school uniform culture into the design of fashion. "Fig. 5" The sailor suit style coat of South Korean brand, plus minus zero, is the transformation of Japanese sailor suit uniform. This kind of design would endow teenagers with vigorous and energetic quality.

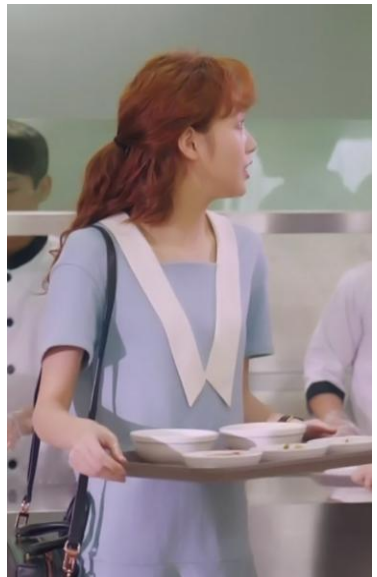

Fig. 4. South Korea film Cheese in the Trap 


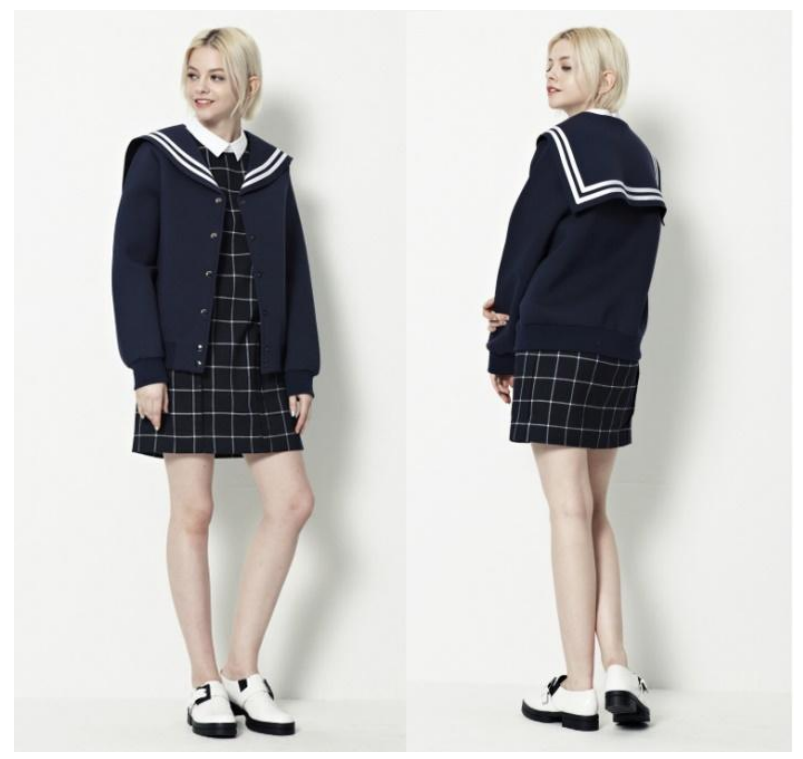

Fig. 5. South Korea fashion brand Plus Minus Zero

To sum up, we have learned the special charm of school uniform culture from the above analysis. The research on school uniform in films and television programs provides a new research direction for the study on films and television programs, which in turn would help us to feel the artistic charm of films and television programs from another side.

\section{REFERENCES}

[1] Lim Song-mi, Lee Mi-Sook, A study of School Uniform Design in the Mass Media. Journal of Fashion Business, 2010 (Vol.14 No.2).

[2] Yang Yuxuan, He Yang. Analysis on the Reasons of the Prevailing of Sailor Suit in Japanese School Uniform $[\mathrm{J}]$. Shandong Textile and Econimy, 2011(11).

[3] Deng Wuying. On the visual expression of Dressing Culture in Films and Television Programs [J]. Criticism and Creation, 2006 (01).

[4] He Wei. On the Influence and Function of Clothing to Films and Television Programs [J]. Movie Literature, 2010(05). 